BMJ Open

Sport \&

Exercise

Medicine

\title{
Efficacy of gross motor skill interventions in young children: an updated systematic review
}

\author{
Sanne L C Veldman, ${ }^{1}$ Rachel A Jones, ${ }^{1}$ Anthony D Okely ${ }^{1,2}$
}

To cite: Veldman SLC, Jones RA, Okely AD. Efficacy of gross motor skill interventions in young children: an updated systematic review. BMJ Open Sport Exerc Med 2016;2: e000067. doi:10.1136/ bmjsem-2015-000067

- Prepublication history for this paper is available online. To view these files please visit the journal online (http://dx.doi.org/10.1136/ bmjsem-2015-000067).

Accepted 17 November 2015

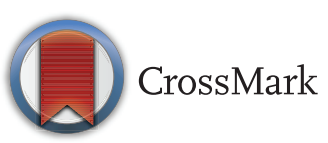

${ }^{1}$ Early Start Research Institute, Faculty of Social Sciences, University of Wollongong, Wollongong, New South Wales, Australia ${ }^{2}$ Illawarra Health and Medical Research Institute, University of Wollongong, Wollongong, New South Wales, Australia

Correspondence to Sanne L Veldman; slcv960@uowmail.edu.au

\section{ABSTRACT}

Objective: The objective of this study was to provide an update of the evidence on the efficacy of gross motor development interventions in young children $(0$ 5 years) from 2007 to 2015 .

Methods: Searches were conducted of six electronic databases: PUBMED, Medline (Ovid), ERIC (Ebsco), Embase, SCOPUS and Psychinfo. Studies included any childcare-based, preschool-based, home-based, or community-based intervention targeting the development of gross motor skills including statistical analysis of gross motor skill competence. Data were extracted on design, participants, intervention components, methodological quality and efficacy.

Results: Seven articles were included and all were delivered in early childhood settings. Four studies had high methodological quality. Most studies used trained staff members/educators to deliver the intervention $(86 \%)$ and five studies lasted 18 weeks or more. Six studies reported statistically significant intervention effects.

Conclusions: Despite the proven importance of gross motor skill development in young children and the recommendations made in the previous review, this review highlights the limited studies evaluated to improve such key life skills in young children over the past 8 years.

Trial registration number: CRD42015015826.

\section{INTRODUCTION}

Fundamental or gross motor skills (GMS) are the foundation for many sports and physical activities. From a health perspective, higher levels of GMS are associated with lower body mass index ${ }^{1}$ better cardiorespiratory fitness ${ }^{2}$ and physical activity ${ }^{3}$ as well as enhanced cognitive development ${ }^{4}{ }^{5}$ social development and language skills. ${ }^{6}$ Moreover, children with poor GMS are more likely to have lower self-esteem ${ }^{78}$ and higher levels of anxiety. $^{9}$

GMS proficiency in young children is suboptimal $^{10} 11$ and given the short-term and long-term consequences of poor skills, interventions targeting the improvement of these skills are needed. In 2009, Riethmuller et $a l^{12}$

\section{What are the new findings}

- The quality of the intervention studies has improved, but not the quantity since only seven studies have examined gross motor skill interventions in young children ( $>5$ years) over the past 8 years.

- Professional development of the educators in the area of gross motor skills development should be an important component in future interventions to increase the quality of their practice in early childhood settings.

- Parent involvement in interventions is recommended given their important role in developing gross motor skills through role modelling and providing opportunities, encouragement and support.

conducted a systematic review, which assessed the efficacy of interventions designed to increase GMS in young children (<5 years). Seventeen articles were included, of which most were controlled trials $(65 \%)$ and implemented in early childhood settings (65\%). More than half of the studies reported statistically significant improvements $(60 \%)$. The review highlighted the limited quantity and quality of interventions in young children and the lack of high-quality evidence in this area.

In recent years, several studies have reported on the relationship between GMS and other important developmental areas adding evidence to the importance of GMS development. Jenni et $a l^{13}$ found positive correlations between motor and intellectual functions, and Leonard and $\mathrm{Hill}^{6}$ highlighted the significant relationship with the development of social skills and language. As this is an area of interest internationally, there is a need for a further review which updates the evidence in this area and gives directions for further research to promote GMS development. The aim of the current review was to provide an update of the evidence on the efficacy of gross motor 
development interventions in young children $(0-$ 5 years) and to provide recommendations for further research in this area.

\section{METHODS}

This review followed the guidelines in the Preferred Reporting Items for Systematic Review and Meta-analysis (PRISMA) statement. $^{14}$

\section{Eligibility criteria}

Types of participants

Children between the ages of 0 and 5 years (mean age $>5$ years) enrolled in kindergarten, childcare centres, preschool or community services, but not yet at school.

\section{Types of intervention}

Any childcare-based, preschool-based, home-based or community-based intervention targeting the development of GMS. Targeted skills could include locomotor and object control skills.

\section{Types of outcome measures}

Studies were included if they reported statistical analysis of GMS competence with measurements taken pre- and at least once postintervention and included either process (knowledge of performance) or product (knowledge of results) assessments of at least one skill.

\section{Types of studies}

Randomised controlled trials (RCTs) with experimental and quasi-experimental designs and single group pretest and post-test designs. Studies were excluded if they: (1) targeted groups from special populations (eg, children with cerebral palsy or autism); (2) no full text was available; (3) the research was not published in English.

\section{Information sources and search}

Six electronic databases were searched: PUBMED, Medline (Ovid), ERIC (Ebsco), Embase, SCOPUS and Psychinfo with a restriction on the start of the publication date to 2007 and before given the previous systematic review. ${ }^{12}$ The search was performed in January 2015. The following search terms were used: toddler OR childcare OR day care OR preschool* OR 'early childhood' OR 'community-based' AND random* OR trial OR evaluation OR programme OR pilot AND 'motor skill*' OR 'movement skill*' OR 'motor development'. Additional studies were found through scanning reference lists of included articles.

\section{Study selection}

After searching the databases, one of the authors (SLV) removed all duplicates and two authors (RAJ/SLV) screened all titles and abstracts in a non-blinded standardised way. These were screened for inclusion, by dividing them into three groups: 'yes, no, or maybe'. All decisions were checked by another author (ADO) and a discussion followed when there were any disagreements. The full text for the remaining articles was retrieved.

\section{Data collection process}

After the study selection process, one author (SLV) extracted data on methodology, characteristics of participants, interventions programme, GMS measurement and results from the selected studies. These data were checked by another author (RAJ).

\section{Methodological quality}

Methodological Quality was assessed by using a 10-item quality assessment scale (see table 1) adapted from previously used methodological assessments. ${ }^{15}{ }^{16}$ Each included article was assessed by two authors (ADO/SLV) individually. Any disagreements between the authors were resolved by discussion. An article was classified as high methodological quality when it scored $\geq 5$ for a controlled trial and $\geq 6$ for a randomised controlled trial. $^{16}$

\section{Synthesis of results}

The following data were extracted from the articles: research design and setting, sample size and mean age, total duration of the intervention in weeks, intervention groups, intervention content, measurement of motor skills and results.

\section{RESULTS}

\section{Overview of studies}

Study selection is displayed in figure 1 . The initial search identified 5829 hits. After removing duplicates $(n=1336)$ and screening of titles and abstracts $(n=4493), 10$ articles remained. The full-texts of these articles were retrieved and seven articles were included.

\section{Study characteristics}

Table 2 shows characteristics of the studies. Five studies were published between 2011 and 2014. ${ }^{17-21}$ Three studies were conducted in the USA ${ }^{17} 1822$ two studies were conducted in Australia ${ }^{20} 23$ and the others were conducted in Switzerland ${ }^{19}$ and Greece. ${ }^{21}$ Some studies recruited centres based on region ${ }^{19}{ }^{21}$ or within an existing program ${ }^{17}$ while others worked together with the (local) government ${ }^{23}$ or childcare organisations. ${ }^{18} 2022$ Two studies involved parents.

There were six randomised controlled trials ${ }^{17-19} 202223$ and one quasi-experimental study. ${ }^{21}$ The sample size of the studies varied from $71^{17}$ to 835 participants. ${ }^{19}$

\section{Implementation}

All interventions took place in early childhood settings and most were delivered by setting staff. $^{17-19} 2023$ Professional development sessions were offered prior to the interventions (1-5 sessions). One study used the researcher and a doctoral student to deliver the programme. ${ }^{22}$ The length of the interventions varied from 
Table 1 Methodological quality assessment items ${ }^{15}$

\begin{tabular}{ll}
\hline Item & Description \\
\hline Key baseline characteristics are presented \\
separately for treatment groups (age, and at least \\
one outcome measure) and for cluster randomised \\
controlled trials and controlled trials, positive if \\
baseline outcomes were statistically tested and \\
results of tests were provided \\
Randomisation procedure clearly and explicitly \\
described and adequately carried out (generation of \\
allocation sequence, allocation concealment and \\
implementation) \\
Validated measures of motor development used \\
(validation in same age group reported and/or cited) \\
Drop out described and $\leq 20 \%$ for <6-month \\
follow-up or $\leq 30 \%$ for $\geq 6$-month follow-up \\
Blinded outcome assessments (positive when \\
those responsible for assessing motor development \\
at outcome were blinded to group allocation of \\
individual participants) \\
Motor development assessed a minimum of \\
6 months after pretest \\
Intention to treat analysis for motor development \\
outcomes(s) (participants analysed in group they \\
I $\quad \begin{array}{l}\text { were originally allocated to, and participants not } \\
\text { excluded from analyses because of non-compliance } \\
\text { to treatment or because of some missing data) }\end{array}$ \\
Potential confounders accounted for in motor \\
development analysis (eg, baseline score, group/ \\
cluster, age) \\
Summary results for each group+treatment effect \\
(difference between groups)+its precision (eg, 95\% \\
Cl) \\
Power calculation reported, and the study was \\
adequately powered to detect hypothesised \\
relationships
\end{tabular}

2 to 10 months and frequency ranged from two to five sessions per week. The session duration varied from 15 to $40 \mathrm{~min}$, with two studies not reporting a specified duration. ${ }^{1924}$ Six interventions consisted of a structured programme and included: implementing only one GMS per session; ${ }^{17}$ focusing on a different GMS each week; ${ }^{18}$ providing a circuit in which children chose their own task and difficulty; ${ }^{23}$ or a structured programme in combination with either supervised free play or unstructured activities. $^{20}$ Two studies involved parents in the intervention. $^{1819}$

\section{Efficacy}

The Test of Gross Motor Development 2 (TGMD-2) was the most common measure. ${ }^{17}$ Six studies reported a statistically significant effect of the intervention. ${ }^{17} 18$ 20-23 Three studies reported a significant effect on the total scores of motor skills ${ }^{18} 20^{21}$ and three studies reported significant effects on either locomotor skills, object control skills or on individual skills. ${ }^{17} 202223$

\section{Methodological quality}

Table 3 displays the methodological quality assessment outcomes. Agreement was on $85 \%$ of the 60 items. Four studies had high methodological quality. ${ }^{17} 192023$

\section{DISCUSSION}

This review examined literature published between June 2007 and January 2015 on interventions to improve GMS in young children ( $0-5$ years). Seven studies were included and $86 \%$ found evidence that interventions are successful. Since developing GMS has been recommended as part of national physical activity guidelines for this age group in three countries (which have all been released since the original review), ${ }^{24-26}$ it is interesting that only seven interventions have been reported in the past 8 years. Reasons for a limited implementation of programmes to develop GMS could be: a lack of funding or interest in this area, the complexity of implementing programmes in childcare settings, or a lack of competence and confidence in setting staff.
Figure 1 PRISMA flowchart of studies through the review process.

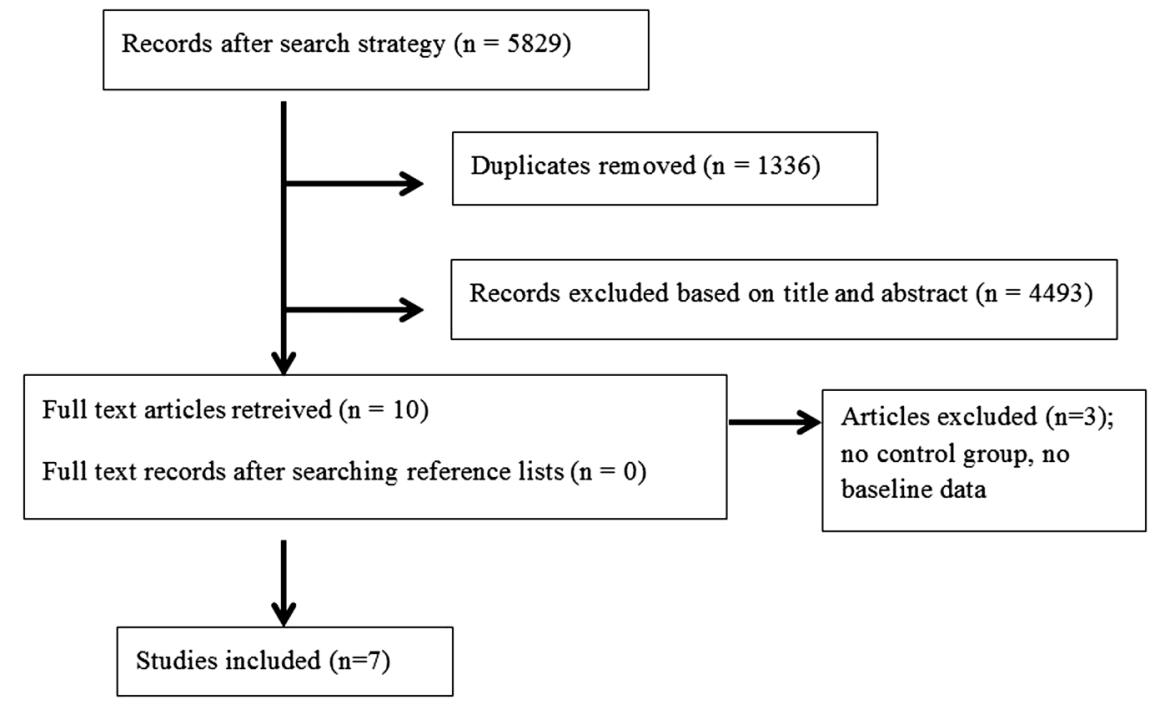


Table 2 Description of study characteristics

\begin{tabular}{|c|c|c|c|c|c|c|c|}
\hline $\begin{array}{l}\text { Reference } \\
\text { (author, year, } \\
\text { country) }\end{array}$ & $\begin{array}{l}\text { Design and } \\
\text { setting }\end{array}$ & Sample & $\begin{array}{l}\text { Intervention } \\
\text { length }\end{array}$ & Intervention groups & Intervention content & $\begin{array}{l}\text { Motor skill } \\
\text { measurement }\end{array}$ & Results \\
\hline $\begin{array}{l}\text { Alhassan et al } \\
2012, \text { USA }^{17}\end{array}$ & $\begin{array}{l}\text { RCT, preschool } \\
\text { children }\end{array}$ & $\begin{array}{l}\mathrm{N}: \mathrm{INT}=43, \mathrm{CON}=28 \\
\text { mean age }=4.3 \text { years }\end{array}$ & 6 months & $\begin{array}{l}\text { INT: Physical activity } \\
\text { intervention, } \\
\text { CON: unstructured } \\
\text { free playtime }\end{array}$ & $\begin{array}{l}\text { INT: Teacher-taught locomotor } \\
\text { skill-based physical activity } \\
\text { programme. } 30 \mathrm{~min}, 5 \times / \text { week. } \\
\text { CON: Unstructured free playtime }\end{array}$ & TGMD-2 & $\begin{array}{l}\text { INT>CON fol } \\
\text { leaping skills } \\
(p<0.009)\end{array}$ \\
\hline $\begin{array}{l}\text { Bellows et al } \\
2013, \text { USA }^{18}\end{array}$ & $\begin{array}{l}\text { RCT, early } \\
\text { childhood settings }\end{array}$ & $\begin{array}{l}\mathrm{N}: \mathrm{INT}=98, \mathrm{CON}=103 \\
\text { mean age }=4.3 \text { years }\end{array}$ & 18 weeks & $\begin{array}{l}\text { INT: The Food } \\
\text { Friends: Get Movin' } \\
\text { With Mighty Moves } \\
\text { Programme } \\
\text { CON: Food Friends, } \\
\text { a 12-week nutrition } \\
\text { programme }\end{array}$ & $\begin{array}{l}\text { INT: Motor skill intervention } \\
\text { programme. } \\
15-20 \text { min, } 4 \times \text { /week. Nutrition } \\
\text { programme, } \\
12 \text { weeks. } \\
\text { CON: Nutrition programme, } \\
\text { 12-week }\end{array}$ & PDMS-2 & $\begin{array}{l}\text { INT>CON } \\
(p<0.001)\end{array}$ \\
\hline $\begin{array}{l}\text { Bonvin et al } \\
2013 \text {, } \\
\text { Switzerland }^{19}\end{array}$ & $\begin{array}{l}\mathrm{RCT} \text {, child care } \\
\text { centres }\end{array}$ & $\begin{array}{l}\mathrm{N}=648, \text { (baseline), } \mathrm{N}: \\
\mathrm{INT}=187, \mathrm{CON}=202 \\
\text { (follow-up), mean } \\
\text { age=3.3 years }\end{array}$ & 10 months & $\begin{array}{l}\text { INT: Physical activity } \\
\text { intervention, } \\
\text { CON: Regular care }\end{array}$ & $\begin{array}{l}\text { INT: Physical activity programme } \\
\text { designed to intervene at individual } \\
\text { and environmental level. No time } \\
\text { demands. } \\
\text { CON: no intervention }\end{array}$ & $\begin{array}{l}\text { Zurich } \\
\text { Neuromotor } \\
\text { Assessment } \\
\text { Test }\end{array}$ & $\mathrm{INT}=\mathrm{CON}$ \\
\hline $\begin{array}{l}\text { Hardy et al } \\
2010, \\
\text { Australia }^{23}\end{array}$ & $\begin{array}{l}\text { RCT, preschool } \\
\text { children }\end{array}$ & $\begin{array}{l}\mathrm{N}: \mathrm{INT}=263, \\
\mathrm{CON}=167, \text { mean } \\
\text { age }=4.4 \text { years }\end{array}$ & 20 weeks & $\begin{array}{l}\text { INT: Munch and } \\
\text { Move, } \\
\text { CON: Regular care }\end{array}$ & $\begin{array}{l}\text { INT: Resource containing games } \\
\text { and learning experiences related to } \\
\text { healthy eating and fundamental } \\
\text { movement skill activities. No time } \\
\text { demands. } \\
\text { CON: no intervention }\end{array}$ & TGMD-2 & $\begin{array}{l}\text { INT }>\text { CON } \\
(p<0.001)\end{array}$ \\
\hline $\begin{array}{l}\text { Jones et al } \\
2011, \\
\text { Australia }^{20}\end{array}$ & $\begin{array}{l}\text { RCT, early } \\
\text { childhood settings }\end{array}$ & $\begin{array}{l}\mathrm{N}: \mathrm{INT}=52, \mathrm{CON}=45, \\
\text { mean age }=4.1 \text { years }\end{array}$ & 20 weeks & $\begin{array}{l}\text { INT: Movement skill } \\
\text { development } \\
\text { physical activity } \\
\text { programme. } \\
\text { CON: Usual care }\end{array}$ & $\begin{array}{l}\text { INT: Structured lessons and } \\
\text { unstructured activities for children. } \\
20 \text { min, 3x/week. } \\
\text { CON: no intervention }\end{array}$ & TGMD-2 & $\begin{array}{l}\text { INT>CON } \\
(p=.00)\end{array}$ \\
\hline $\begin{array}{l}\text { Robinson and } \\
\text { Goodway } \\
\text { 2009, USA }\end{array}$ & $\begin{array}{l}\text { RCT, preschool } \\
\text { children }\end{array}$ & $\begin{array}{l}\mathrm{N}: \text { INT }(\mathrm{LA})=38, \text { INT } \\
(\mathrm{MM})=39, \mathrm{CON}=40, \\
\text { mean age }=3.8 \text { years }\end{array}$ & 9 weeks & $\begin{array}{l}\text { INT: LA or mastery } \\
\text { motivational (MM) } \\
\text { instructional climate } \\
\text { CON: Comparison } \\
\text { group }\end{array}$ & $\begin{array}{l}\text { INT: Motor skill intervention } \\
\text { programme. } 30 \text { min, } 2 \times / \text { week. } \\
\text { LA: Students following guidance } \\
\text { and directions from instructor. } \\
\text { MM: Students navigated } \\
\text { independently through activity } \\
\text { stations. } \\
\text { CON: Typical Head Start } \\
\text { curriculum }\end{array}$ & TGMD-2 & $\begin{array}{l}\text { INT>CON } \\
(p=.001)\end{array}$ \\
\hline $\begin{array}{l}\text { Tsapakidou } \\
\text { et al } 2014 \text {, } \\
\text { Greece }{ }^{21}\end{array}$ & $\begin{array}{l}\text { Quasi-experiment, } \\
\text { nursery school }\end{array}$ & $\begin{array}{l}\mathrm{N}: \text { INT }=49, \mathrm{CON}=49 \text {, } \\
\text { ages } 3.5-5 \text { years }(\mathrm{no} \\
\text { mean age reported) }\end{array}$ & 2 months & $\begin{array}{l}\text { INT: Motor skill } \\
\text { development } \\
\text { programme } \\
\text { CON: Daily routine } \\
\end{array}$ & $\begin{array}{l}\text { INT: Motor skill intervention } \\
\text { programme, } 30-40 \text { min, } 2 \times / \text { week. } \\
\text { CON: No intervention }\end{array}$ & TGMD-2 & $\begin{array}{l}\text { INT>CON } \\
(p=<0.005)\end{array}$ \\
\hline
\end{tabular}

the test of gross motor development 2 . 
Table 3 Methodological quality assessment

\begin{tabular}{|c|c|c|c|c|c|c|c|}
\hline Methodological quality item & $\begin{array}{l}\text { Alhassan } \\
\text { et al } 2012^{17}\end{array}$ & $\begin{array}{l}\text { Bellows } \\
\text { et al } 2013^{18}\end{array}$ & $\begin{array}{l}\text { Bonvin } \\
\text { et al } \\
2013^{19}\end{array}$ & $\begin{array}{l}\text { Hardy } \\
\text { et al } \\
2010^{23}\end{array}$ & $\begin{array}{l}\text { Jones } \\
\text { et al } \\
2011^{20}\end{array}$ & $\begin{array}{l}\text { Robinson } \\
\text { and Goodway } \\
2009^{22}\end{array}$ & $\begin{array}{l}\text { Tsapakidou } \\
\text { et al } 2014^{21}\end{array}$ \\
\hline $\begin{array}{l}\text { Key baseline characteristics } \\
\text { reported separately for each group }\end{array}$ & + & - & + & - & - & - & - \\
\hline $\begin{array}{l}\text { Randomisation procedure clearly } \\
\text { described }\end{array}$ & - & - & + & - & + & - & -- \\
\hline Valid measure of FMS & + & + & + & + & + & + & + \\
\hline $\begin{array}{l}\text { Dropout } \leq 20 \% \text { for }<6 \text { months } \\
\text { follow-up or } \leq 30 \% \text { for } \geq 6 \text { months } \\
\text { follow-up }\end{array}$ & + & - & + & + & + & + & + \\
\hline Assessor blinding & - & - & + & + & + & - & - \\
\hline $\begin{array}{l}\text { Motor development assessed a min } \\
\text { of } 6 \text { months after pretest }\end{array}$ & + & - & + & + & - & - & - \\
\hline Intention-to-treat analysis & - & - & + & + & + & - & + \\
\hline $\begin{array}{l}\text { Potential confounders accounted } \\
\text { for in analysis }\end{array}$ & + & + & + & + & + & - & - \\
\hline $\begin{array}{l}\text { Summary results presented } \\
\text { +treatment effect+precision } \\
\text { estimates }\end{array}$ & + & - & + & + & + & - & - \\
\hline Power calculation reported & - & - & + & + & - & - & - \\
\hline Total score & 6 & 2 & 10 & 8 & 7 & 2 & 3 \\
\hline
\end{tabular}

\section{Implementation}

All studies were implemented in early childhood settings. This setting is popular for group RCTs because it is relatively easy to randomise at a whole centre level, and programmes can be incorporated into regular routines. Furthermore, it maximises the number of staff involved and the responsibility of implementation can be shared. Compared to the previous review, the number of RCTs has increased from $29 \%$ to $86 \%$, which is positive given that RCTs are the 'gold standard' in research design.

Setting staff delivered the intervention in six studies and training was offered to increase their competence and confidence in delivering the programme and to enhance professional development. ${ }^{17-19} 20 \quad 2123$ This training varied from a 1 day workshop ${ }^{17} 23$ to several separate workshops spread over different days. ${ }^{19}{ }^{20}$ Professional development of staff is important to enhance their self-efficacy in delivering a programme and to provide them with up-to-date information on the importance of GMS and how to teach them. Especially in young children it is important to enhance their motivation and involvement through people that have experience, are competent and confident. Other advantages of setting staff delivering the intervention have been mentioned in the previous systematic review ${ }^{12}$ and include maximising the potential sustainability of the programme and minimising costs associated with implementation.

As recommended by Riethmuller et $a l^{12}$ parents should play an important role in developing GMS through role modelling and providing opportunities, encouragement and support. ${ }^{12} 24$ However, only two studies involved parents. This was done through home connection materials such as educational handouts and a music $\mathrm{CD}^{18}$ or parent information sessions to inform them on the benefits of physical activity and how to integrate this within their family environment. ${ }^{19}$ It is recommended to actively involve parents in centre-based GMS development programmes and encourage them to practice skills in the home environment ${ }^{12}$ to reinforce the learning that has occurred at the centre and strengthen the relationship between the centre and home setting. Informing and guiding parents in how to practice GMS, the duration of practice and how to motivate their children can be done in several ways such as through information sessions, by handing out home materials or via email and the use of social media.

While only seven studies were identified, the sample sizes, duration and programme content varied widely. Most studies included in this review recruited whole childcare centres, which helps to maximise sample size.

The duration of the programmes varied between 2 and 10 months. Four programmes lasted $\geq 20$ weeks, ${ }^{18} 202223$ an increase compared with the average of 12 weeks in the previous review. Intervention sessions were delivered between two and five times a week and the average duration of the intervention sessions was around $20 \mathrm{~min}$. On average this gives a greater intervention 'dose' compared to the studies in the previous review where there was approximately $1 \mathrm{~h}$ of instruction per week. Based on this current evidence it seems that a higher intervention 'dose' with at least two sessions a week may contribute to the effectiveness of interventions.

\section{Efficacy}

Six studies found significant intervention effects. ${ }^{17} 18$ 20-23 Even though Bonvin et $a l^{19}$ had high methodological 
quality, they did not collect any data on the exact amount of daily physical activity time or the use of any specific curriculum, which means the intensity might have been inadequate and there was no control on what activities were done.

Not all studies clearly described their intervention programme which makes it difficult to compare intervention components. Therefore, no key components could be identified that would contribute to a successful intervention.

\section{Methodological quality}

Four included articles had high methodological quality. Compared to the review of Riethmuller $e t a l,{ }^{12}$ the percentage has increased from $<20 \%$ to $57 \%$, and the high number of RCTs might have contributed to this. Power calculations have been recommended to ensure that appropriate statistical analyses could be performed. ${ }^{14}$ However, only two studies conducted a power calculation. ${ }^{19}{ }^{23}$ A reason why two other included studies did not perform power calculations could be because they were pilot studies and therefore not adequately powered to detect statistical significances. ${ }^{17}{ }^{20}$ For future studies, however, it is important to conduct power calculations in order to appropriately test the effectiveness of these GMS development programmes in young children.

\section{Strengths and limitations}

This review has a number of strengths. These include searching multiple databases, extraction of extensive study details from the articles, methodological quality assessments with high agreement levels and alignment with the PRISMA statement. ${ }^{14}$ Limitations include the following: the effectiveness of interventions could not be compared because of different instruments that were used to assess GMS, only a small number of updated studies were found, and studies had to be published in English.

\section{Recommendations}

Development of GMS in young children is important. When given the opportunity and encouragement to learn and practice GMS, children are able to master these skills before the end of childhood. ${ }^{27}$ The recommendations made in the previous review are still important: ${ }^{12}$ utilising a partnership approach in which researchers and childcare staff work together to share responsibilities, minimise the burden and support each other; programme facilitators should be chosen carefully because their competence, confidence and enthusiasm influences children's participation; parents should be involved; conducting sample size calculations to ensure appropriate statistical analysis; and improving the methodological quality of interventions (alignment with the CONSORT or TREND statement).Additionally, the following recommendations can be made:

1. More high-quality GMS interventions are needed based on the current evidence of relationships between GMS development and other developmental areas and extra funding should be provided to support the development of these interventions.

2. Intervention components should be clearly described in order to compare the different intervention programmes and determine which components contributed to the effectiveness of the intervention. For future research, this is important in order to implement the most optimal intervention programme.

3. Based on the current evidence it seems that a higher intervention 'dose' with at least two sessions a week may contribute to the effectiveness of interventions.

4. Consistency in GMS assessment is important to compare results between interventions and conduct meta-analysis.

\section{CONCLUSION}

This review highlights the limited studies evaluated to improve GMS in young children over the past 8 years. This is surprising since the importance of GMS development in young children has been proven and given the recommendations made in the previous review.

Programmes designed to increase the development of GMS have been promising although further research regarding efficacy and the optimal dose of implementation is required. As stated in the previous review, parents play an important role in developing GMS in their children. Up to now, few studies have focused on involving parents and children to increase the development of GMS and therefore, this should be a focus for further research. Also, professional development of the educators in this area should be an important component in future interventions to increase the quality of their practice in early childhood settings.

Competing interests None declared.

Provenance and peer review Not commissioned; internally peer reviewed.

Open Access This is an Open Access article distributed in accordance with the Creative Commons Attribution Non Commercial (CC BY-NC 4.0) license, which permits others to distribute, remix, adapt, build upon this work noncommercially, and license their derivative works on different terms, provided the original work is properly cited and the use is non-commercial. See: http:// creativecommons.org/licenses/by-nc/4.0/

\section{REFERENCES}

1. Okely A, Booth M, Chey T. Relationships between body composition and fundamental movement skills among children and adolescents. Res Q Exerc Sport 2004;75:238-47.

2. Okely A, Booth M, Patterson J. Relationship of cardiorespiratory endurance to fundamental movement skill proficiency among adolescents. Pediatr Exerc Sci 2001;13:380-91.

3. Logan S, Robinson L, Webster E, et al. The relationship between motor competence and physical activity engagement during childhood: a systematic review. Kinesiol Rev 2014;4;416-26.

4. Best JR. Effects of physical activity on children's executive function: contributions of experimental research on aerobic exercise. Dev Rev 2010;30:331-51.

5. Piek J, Dawson L, Smith L, et al. The role of early fine and gross motor development on later motor and cognitive ability. Hum Mov Sci 2008;27:668-81. 
6. Leonard H, Hill E. Review: The impact of motor development on typical and atypical social cognition and language: a systematic review. J Child Adolesc Ment Health 2014;19; 163-70.

7. Piek J, Baynam G, Barrett N. The relationship between fine and gross motor ability, self-perceptions and self-worth in children and adolescents. Hum Mov Sci 2006;25:65-75.

8. Ulrich B. Perceptions of physical competence, motor competence, and participation in organized sport: their interrelationships in young children. Res Q Exerc Sport 1987;58:57-67.

9. Skinner R, Piek J. Psychosocial implications of poor motor coordination in children and adolescents. Hum Mov Sci 2001;20:73-94.

10. Hardy L, Reinten-Reynolds T, Espinel P, et al. Prevalence and correlates of low fundamental movement skill competency in children. Pediatrics 2012;130:e390-8

11. Okely A, Booth M. Mastery of fundamental movement skills among children in New South Wales: prevalence and sociodemographic distribution. J Sci Med Sport 2004;7:358-72.

12. Riethmuller A, Jones R, Okely A. Efficacy of interventions to improve motor development in young children: a systematic review. Pediatrics 2009;124:e782-92.

13. Jenni $\mathrm{O}$, Chaouch $\mathrm{A}$, Caflisch J, et al. Correlations between motor and intellectual functions in normally developing children between 7 and 18 years. Dev Neuropsychol 2013;38:98-113.

14. Moher D, Liberati A, Tetziaff J, et al. Preferred reporting items for systematic reviews and meta-analysis: the PRISMA statement. PLoS Med 2009;6:e1000097.

15. Altman D, Schulz K, Moher D, et al. The revised CONSORT statement for reporting of randomized controlled trials. Ann Intern Med 2001;134:663-94.

16. Van Sluijs E, McMinn A, Griffin S. Effectiveness of interventions to promote physical activity in children and adolescents: systematic review of controlled trials. BMJ 2007;335:703.

17. Alhassan S, Nwaokelemeh $\mathrm{O}$, Ghazarian $\mathrm{M}$, et al. Effects of locomotor skill program on minority preschoolers' physical activity levels. Pediatr Exerc Sci 2012;24:435-49.
18. Bellows LL, Davies PL, Anderson J, et al. Effectiveness of a physical activity intervention for Head Start preschoolers: a randomized intervention study. Am J Occup Ther 2013;67:28-36.

19. Bonvin A, Barral J, Kakebeeke T, et al. Effect of a governmentallyled physical activity program on motor skills in young children attending child care centers: a cluster randomized controlled trial. Int J Behav Nutr Phys Act 2013:10:90.

20. Jones R, Riethmuller A, Hesketh $\mathrm{K}$, et al. Promoting fundamental movement skill development and physical activity in early childhood settings: a cluster randomized controlled trial. Pediatr Exerc Sci 2011;23:600-15.

21. Tsapakidou A, Stefanidou S, Tsompanaki E. Locomotor development of children aged 3.5 to 5 years in nursery schools in Greece. Rev Eur Stud 2014;1-6.

22. Robinson LE, Goodway JD. Instructional climates in preschool children who are at-risk. Part I: object-control skill development. Res Q Exerc Sport 2009;80:533-42.

23. Hardy L, King L, Kelly B, et al. Munch and Move: evaluation of a preschool healthy eating and movement skill program. Int J Behav Nutr Phys Act 2010;7:80.

24. Department of Health. Move and Play every day. In: Australian Government DoH, ed. Australia. 2014. http://www.health.gov.au/ internet/main/publishing.nsf/content/F01F92328EDADA5BCA257BF 0001E720D/\$File/Move\%20and\%20play\%20every\%20day\% 200-5yrs.PDF

25. Department of Health Social Services and Public Safety. Physical activity guidelines for early years (under $5 \mathrm{~s}$ ). In: Department of Health SSaPS, ed. United Kingdom, 2011. https://www.gov.uk/ government/uploads/system/uploads/attachment_data/file/213737/ dh_128142.pdf

26. Canadan Society for Exercise Physiology and Participation. Canadian physical activity guidelines for the early years: 0-4 years. In: Participation. CSfEPa, ed. Canada, 2012. http://www. csep.ca/CMFiles/Guidelines/CSEP_PAGuidelines_early-years_ en.pdf

27. Gallahue D, Donnelly F. Developmental physical education for all children. 4th edn. Human Kinetics, 2003. 